\title{
The KULTURisk Regional Risk Assessment methodology for water-related natural hazards - Part 1: Physical-environmental assessment
}

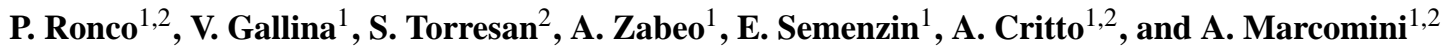 \\ ${ }^{1}$ Department of Environmental Sciences, Informatics and Statistics, Ca' Foscari University of Venice, Venice, Italy \\ ${ }^{2}$ Euro-Mediterranean Center on Climate Change (CMCC), Impacts on Soil and Coast Division, Lecce, Italy
}

Correspondence to: A. Marcomini (marcom@unive.it)

Received: 9 June 2014 - Published in Hydrol. Earth Syst. Sci. Discuss.: 11 July 2014

Revised: 4 November 2014 - Accepted: 17 November 2014 - Published: 23 December 2014

\begin{abstract}
In recent years, the frequency of catastrophes induced by natural hazards has increased, and flood events in particular have been recognized as one of the most threatening water-related disasters. Severe floods have occurred in Europe over the last decade, causing loss of life, displacement of people and heavy economic losses. Flood disasters are growing in frequency as a consequence of many factors, both climatic and non-climatic. Indeed, the current increase of water-related disasters can be mainly attributed to the increase of exposure (elements potentially at risk in flood-prone area) and vulnerability (i.e. economic, social, geographic, cultural and physical/environmental characteristics of the exposure). Besides these factors, the undeniable effect of climate change is projected to strongly modify the usual pattern of the hydrological cycle by intensifying the frequency and severity of flood events at the local, regional and global scale. Within this context, the need for developing effective and pro-active strategies, tools and actions which allow one to assess and (possibly) to reduce the flood risks that threatens different relevant receptors becomes urgent. Several methodologies to assess the risk posed by water-related natural hazards have been proposed so far, but very few of them can be adopted to implement the last European Flood Directive (FD). This paper is intended to introduce and present a state-of-the-art Regional Risk Assessment (RRA) methodology to appraise the risk posed by floods from a physical-environmental perspective. The methodology, developed within the recently completed FP7KULTURisk Project (Knowledge-based approach to develop a cULTUre of Risk prevention - KR) is flexible and can be adapted to different case studies (i.e. plain rivers, mountain
\end{abstract}

torrents, urban and coastal areas) and spatial scales (i.e. from catchment to the urban scale). The FD compliant KR-RRA methodology is based on the concept of risk being function of hazard, exposure and vulnerability. It integrates the outputs of various hydrodynamic models with site-specific bio-geophysical and socio-economic indicators (e.g. slope, land cover, population density, economic activities etc.) to develop tailored risk indexes and GIS-based maps for each of the selected receptors (i.e. people, buildings, infrastructure, agriculture, natural and semi-natural systems, cultural heritage) in the considered region. It further compares the baseline scenario with alternative scenarios, where different structural and/or non-structural mitigation measures are planned and eventually implemented. As demonstrated in the companion paper (Part 2, Ronco et al., 2014), risk maps, along with related statistics, allow one to identify and classify, on a relative scale, areas at risk which are more likely to be affected by floods and support the development of strategic adaptation and prevention measures to minimizing flood impacts. In addition, the outcomes of the RRA can be eventually used for a further socio-economic assessment, considering the tangible and intangible costs as well as the human dimension of vulnerability.

\section{Introduction}

Extreme weather and climate events, the physical contributors to disaster risk, interacting with exposed and vulnerable human and natural systems, can lead to severe catastrophes 


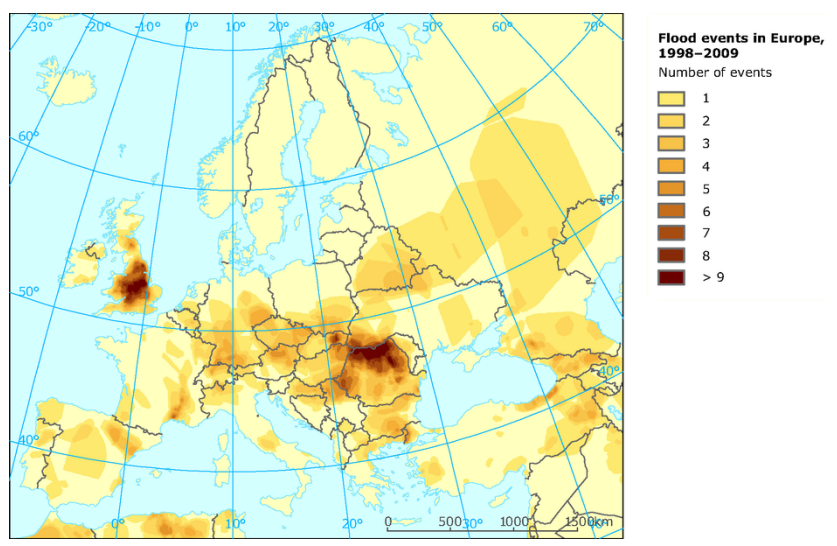

Figure 1. Occurrence of major floods in Europe in the period 19982009; Source: http://www.eea.europa.eu/legal/copyright). Copyright holder: European Environment Agency (EEA).

(IPCC, 2012). Floods are the most threatening water-related disaster which affects human life, property and infrastructure (Hewitt, 1997; Penning-Rowsell et al., 2005; Bates et al., 2008; Balica et al., 2009; Kubal et al., 2009), with an increasing occurrence as a consequence of many factors both climatic (increase of heavy precipitation, changing in water natural cycle) and non-climatic (land use change, increase in population, economic wealth, human activities in hazardprone areas and urban development). The combination of severe consequences, rarity, and human and physical factors makes disasters difficult to study. However, there are scientific evidence of increased precipitation intensity, which implies that extreme flood events might become more frequent (Mitchell, 2003; Hirabayashi et al., 2013). At the same time, consequences for disaster-related risks and impacts related to floods might be exacerbated due to the increase of exposure and vulnerability of elements at risk linked to population dynamics and the associated economic and urban development in flood-prone areas. In fact, differences in vulnerability and exposure arise from non-climatic factors and from multidimensional inequalities often produced by uneven development processes. These differences shape differential risks from climate change (IPCC, 2014).

In Europe, floods, storms and other hydro-meteorological events account for around two-thirds of the damage costs of natural disasters, and these costs have increased since 1980, according to EEA (2012). Between 1998 and 2009, in particular, Europe suffered over 213 major damaging floods that caused 1126 fatalities, the displacement of about half a million people and at least EUR 52 billion in insured economic losses, including the catastrophic floods along the Danube and Elbe rivers in the summer of 2013 (see Fig. 1) (Barredo, 2007).

Traditionally, European flood control and management practices have been focused on reactive practices and largely relied on structural measures, only later supported by spo- radic non-structural measures. Currently, it is widely recognized that a paradigm shift is required to move from defensive to proactive action, towards a culture of prevention by managing the risk of and living with floods (Annamo and Kristiansen, 2012). The latest concept is also supported by the recent outcomes of Viglione et al. (2014) that demonstrate the relevance of a suite of social/cultural/anthropogenic drivers for the characterization of vulnerability patterns in (selected) communities.

In this context, the European Flood Directive (FD) 2007/60/EC (2007) represents an ad hoc legislative framework to support the development of proper flood management strategies, in order to reduce the adverse consequences for human health, the environment, cultural heritage and economic activities resulting from such calamities. According to the FD, risk assessment studies and relative maps enable the visualization of the spatial distribution of (flood) risks in the specific (flood) scenario, by considering the risk as the combination of hazard, exposure and vulnerability and by quantifying, in particular, the number of people and economic activities potentially affected. Eventually, a lack of integrated criteria, methodologies and tools operationally supporting the implementation of such regulations and directives at regional scale has been widely recognized.

In fact, several methodologies have been developed in order to assess flood risk; the choice of one methodology over another largely depends on the objectives of the analysis, availability of data sets, peculiarities of the context of application, level of detail to be achieved and dimensions of risk to be addressed. Cirella et al. (2014) recently published a comprehensive review of current approaches and methodologies for the assessment of risks posed by a wide range of water-related natural hazards (coastal storms, tsunamis, river floods, avalanches, landslides, etc.). Based on different indicators and criteria (e.g. the hazard of concern, conceptual framework, analytical approach, role of experts and stakeholders, elements at risk, spatial scale, input and output, tools and models used, uncertainties, etc.), the review demonstrated that there are very few examples of methodologies that consider the complete suite of elements at risk pointed out by the FD encompassing the entire varieties of risk dimensions (i.e. physical/environmental, social and economic) (Di Baldassarre et al., 2009; Di Baldassarre et al., 2010; Rotach et al., 2012). Most of the available methodologies, in fact, only targeted "classical" receptors, such as buildings, infrastructure or population (e.g. Clausen and Clark, 1990; Citeau, 2003; Forte et al., 2005; DEFRA, 2006; Büchele et al., 2006; Kubal et al., 2009), which are usually analysed separately, in monetary terms, and related damage only, neglecting the coexistence (and synergies) of multiple receptors inhabiting in the same geographical region. Moreover, while most of the approaches made a considerable use of GIS-based tools both for computational and outcome purposes, they were mainly developed for very specific contexts at a very local scale, with an high level of complexity, and 
were data demanding, and they can hardly be employed for a wide range of case studies (e.g. Forte et al., 2005; Meyer et al., 2009; Kubal et al., 2009; Forster et al., 2009). A recent attempt has been made by Balica et al. (2009) in proposing an innovative parametric approach for the estimation of the vulnerability of a system by using only few (readily available) parameters related to that system.

Furthermore, by acknowledging different roots of the vulnerability paradigms embedded in multidisciplinary theories underpinning either a technical or social origin of these concepts, Papathoma-Kohle et al. (2011) and Fuchs et al. (2012) stated that methodologies for structural, economic, institutional or social vulnerability assessment should be interwoven in order to enhance their understanding. In general, efforts to reduce exposure to hazards and to create disasterresilient communities require intersection among disciplines and theories, since human actions cannot be seen independently from environmental features and vice versa (Hufschmidt et al., 2010). Moreover, flood risk assessments are also characterized by considerable uncertainty, which needs to be addressed and clearly communicated to decision makers (Pappenberg et al., 2013). Finally, as suggested by Montanari et al. (2013) through the new "Panta Rhei-Everything Flows" paradigm for hydrological disciplines, the next challenge is to look at these (hydrological) processes as a changing interface between environment and society, whose dynamics are essential to set priorities for (proper, effective and sustainable) environmental management, through an interdisciplinary approach between socio-economic sciences and geosciences.

Accordingly, there is the need to develop comprehensive risk assessment instruments that can integrate information coming from deterministic and probabilistic flood forecasting, with multi-faceted physical/environmental, social and economic aspects of exposure and vulnerability, in order to evaluate the consequences of floods for different elements at risk, as required by the FD. In this paper, the physicalenvironmental dimensions of risk due to floods have been assessed by considering its hazard, exposure and vulnerability components by means of an integrated approach.

The paper will introduce both the conceptual framework and the computational procedure used to assess the physicalenvironmental (relative) risk posed by floods to a selected suite of receptors. Finally, the article will also present a simple but effective algorithm, based on multi-criteria decision analysis (MCDA), to combine the receptor-related relative risks into a single general (total) risk index. The (ultimate) objective of the methodology, successfully applied in several case studies across Europe (see the companion paper, Part 2, Ronco et al., 2014), is to identify and prioritize areas and targets at risk in the considered region, in order to evaluate the benefits of different risk prevention scenarios to support relevant stakeholders in knowledge-based (land-use) planning and decision making.

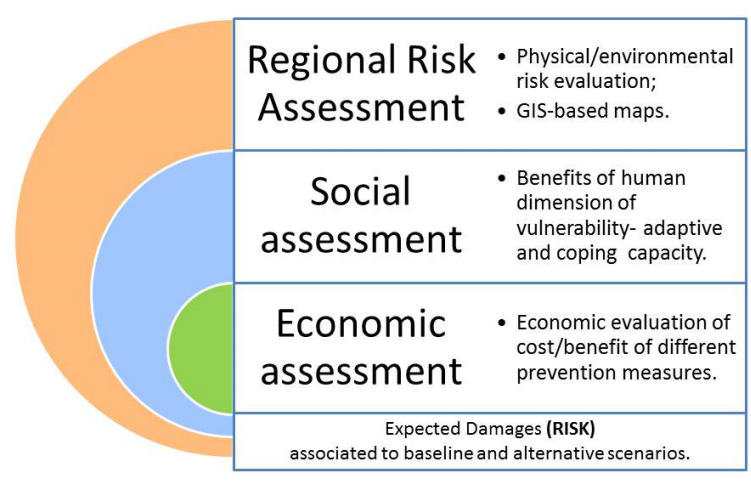

Figure 2. Tiers of analysis for the implementation of the (complete) KULTURisk methodology.

\section{The KULTURisk Regional Risk Assessment (KR-RRA) methodology}

\subsection{Conceptual framework}

The KULTURisk Framework (KR-FWK) developed by Giupponi et al. in 2014, shaped the basis for the development of the presented methodology. By considering three main tiers of analysis, namely (1) the Physical/Environmental Regional Risk Assessment (RRA), (2) the Social Assessment and (3) the Economic Assessment (see Fig. 2), the conceptual framework has been built upon the consolidated formalization of risk being a function of hazard, exposure and vulnerability, defined as (i) hazard, as "the potential occurrence of a natural or human-induced physical event that may cause loss of life, injury, or other health impacts, as well as damage and loss to property, infrastructure, livelihoods, service provision, and environmental resources" (IPCC, 2012); (ii) exposure, as "the presence of people, livelihoods, environmental services and resources, infrastructure, or economic, social, or cultural assets in places that could be adversely affected" (IPCC, 2012); (iii) vulnerability, consisting of susceptibility as a physical/environmental (P/E) component, and adaptive and coping capacities as the social component. The $\mathrm{P} / \mathrm{E}$ component is captured by the likelihood that receptors located in a considered area could potentially be harmed.

The presented study only addresses the first tier of the analysis, namely the RRA that considered the physical/environmental dimension of vulnerability (i.e. susceptibility) to identify and classify physical/environmental risks associated with floods for different receptors. The others two tiers are grouped into a single cluster of assessment, namely the Socio-Economic Assessment (SERRA), where the information used for the RRA are merged with other social and economic indicators and monetary values of the assets at risk (Giupponi et al., 2014). The RRA provides an estimation of the physical/environmental risks that can be used as input for the social and economic tiers of analysis. These tiers can be used separately (i.e. considering only the social or the eco- 


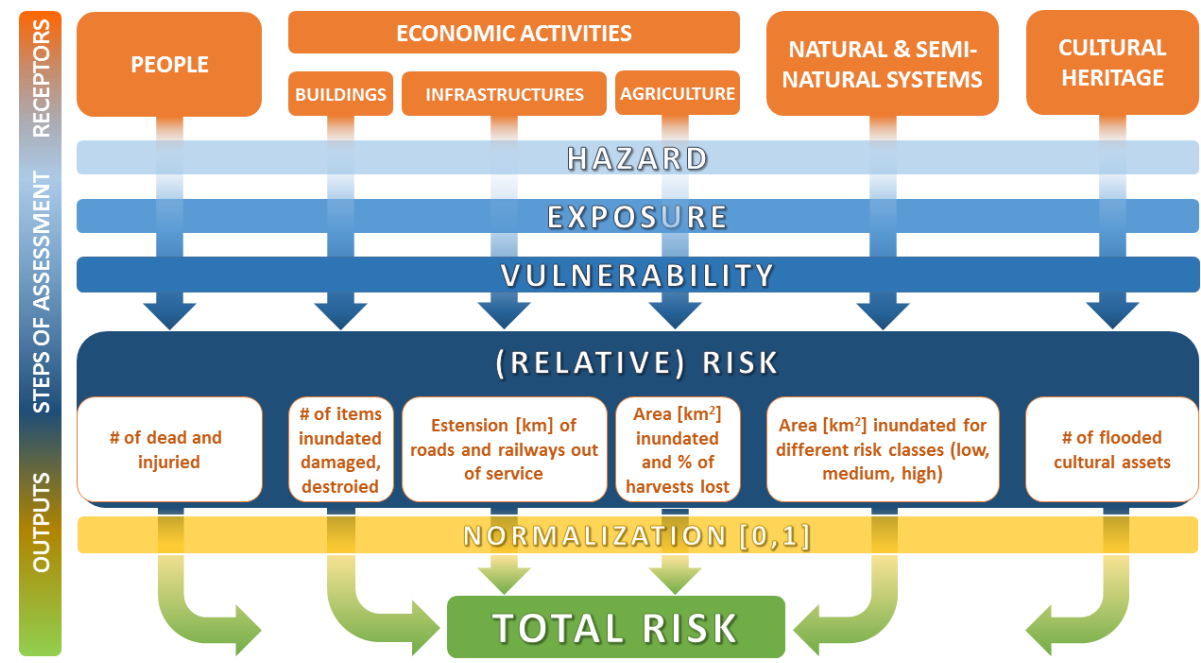

Figure 3. Physical/environmental KR-RRA: receptors, steps and outputs.

nomic dimension) or sequentially (i.e. estimating the effects of the social and value indicators together with the physi$\mathrm{cal} /$ environmental indicators on the expected costs).

\subsection{Regional Risk Assessment: background, features and objectives}

Since its first application in 1997, the RRA approach has been successfully applied in a variety of cases, including marine coastal areas, fjords and hydrographic basins habitats (Landis and Wiegers, 1997). The RRA is aimed at providing a quantitative and systematic way to estimate and compare the impacts of environmental problems that affect large geographic areas (Hunsaker et al., 2010) by considering the presence of multiple habitats, with multiple sources releasing a multiplicity of stressors impacting multiple endpoints (Landis, 2005). Specifically with the aim of ranking potential impacts, targets and areas at risk at the regional scale, the KR-RRA integrates four steps of analysis, as follows:

- hazard assessment is aimed at characterizing the flood pattern by means of relevant metrics (e.g. flow velocity, water depth, flood extension) coming from hydraulic models (deterministic or probabilistic), according to different scenarios to be investigated (baseline or alternative);

- exposure assessment is aimed at identifying the elements at risk. This step requires the analysis of land use/land cover data sets for the localization of people, environmental resources and infrastructure, and social, economic and cultural assets that could be adversely affected;

- susceptibility assessment is aimed at evaluating the degree to which the receptors could be affected by a flood based on physical/environmental site-specific information;

- risk assessment combines the information about a certain flood hazard scenario with the exposure and susceptibility of the examined receptors, providing a first evaluation of risks through the computation of a relative (risk) score. Risk scores varies from 0 (i.e. no risk) to 1 (i.e. highest risk for the considered area). The ranges for risk classes can be defined using different methods (e.g. equal interval, Jenks optimization) and qualitative classes should then be assigned (i.e. low, medium, high risk). After the normalization of the receptor-related risk, a total (integrated) risk index is calculated by means of MCDA functions.

As suggested by the Flood Directive (2007/60/EC), the KRRRA methodology considers the following receptors:

1. People;

2. Economic activities, including (i) buildings, (ii) infrastructure and (iii) agriculture;

3. Natural and semi-natural systems;

4. Cultural heritage.

As depicted in Fig. 3, the main outputs of the RRA are GISbased maps of receptor-related risks and of the total risk.

The KR-RRA method has been developed for analysis at the meso-scale level, adopting the land use/land cover classes proposed by the CORINE (coordination of information on the environment) land cover, as major spatial units of reference (EEA, 2007). However, it is flexible enough to be applied at different spatial levels (i.e. the macro or the micro scales) based on the purposes of the assessment, the geographical extent of the case study and the level of detail 
of input data set. The methodology can be applied in different problem contexts, case studies and spatial scales with the aim of providing a benchmark for the implementation of the Floods Directive at the European level. In addition, GISbased maps and outcomes are useful for communicating the implications of floods in non-monetary terms to stakeholders and decision makers and can be a basis for a knowledgebased management of flood risks by providing information about the indicative number of inhabitants, the type of economic activities, natural systems and cultural heritage potentially affected by flooding. Finally, the KR-RRA methodology allows one to identify and prioritize areas and targets at risk in the considered region and to evaluate the benefits of different prevention scenarios.

In the next paragraphs, the computational procedure to estimate the relative risks, receptor by receptor, will be introduced, starting from the initial setting of the hazard scenario.

\subsection{Scenario development}

In general, the proper selection of robust and reliable scenarios, defined as the plausible outcome of a possible future system state under different circumstances (baseline or alternative scenario), is primary for the quality and the robustness of the risk assessment since it allows one to evaluate the benefits of risk prevention measures. In fact, several approaches can be followed in scenario development, depending on level of detail, data availability and degree of expert involvement. For example, Scholz and Tietje (2002) and Mazzorana et al. (2009) provided a useful insight by classifying the scenario analysis in three different types, among holistic (expert elicitation), model analysis (based on system modelling) and formative scenario analysis, based on qualitatively assessed impact factors and tested in different case studies. When combined with conventional modelling, the latter, by meeting basic, operational and multidimensional principles and integrating bounding uncertainties, represents a robust technique for the development of reliable future settings. According to KR-RRA, the preliminary analysis and screening of different scenarios (baseline and alternative) should be based on different hazard magnitude, probability and/or alternative settings where structural and non-structural mitigation and adaptation measures are planned. These measures can affect (change) both the hazard as well as the exposure and vulnerability patterns. For example, the installation of an early warning system allows one to decrease the vulnerability of the area (AV, see Eq. 3) and, therefore, the relative risk to people, while the re-calibration of the river cross section can contribute to decreasing the hazard metrics (water depth and velocity). Finally, it is worth noticing that the proposed approach does not provide a particular (bounded) method for scenario construction, rather it combines advantages from available techniques and models, depending on their applicability and reliability to the specific case study.
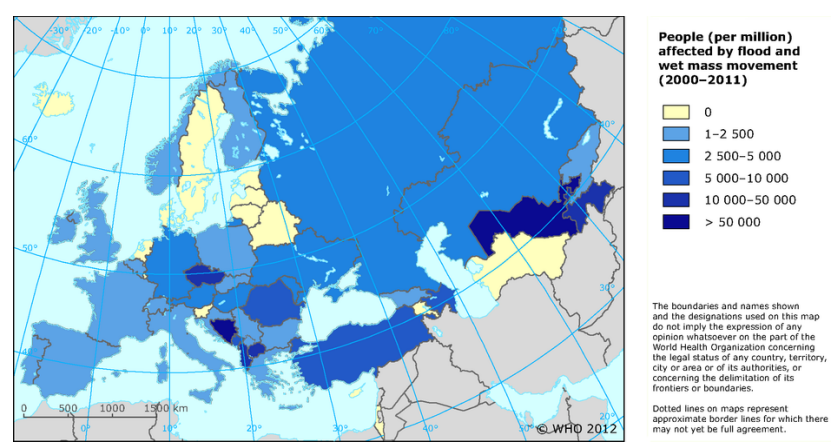

Figure 4. People affected by flood events in Europe in the period 2000-2011, per million population (WHO European Region). Source: http://www.eea.europa.eu/legal/copyright). Copyright holder: World Health Organization Regional Office for Europe (WHO/Europe).

\subsection{Physical/environmental risk assessment for people}

River floods have the potential to cause serious risk to people and are considered as the most threatening water-related disaster that affects human life (Hewitt, 1997; Penning-Rowsell et al., 2005; Balica et al., 2009; Kubal et al., 2009). Both river and coastal flooding affect millions of people in Europe each year; these events have a series of severe consequences on human health through drowning, heart attacks, injuries, infections and psychosocial effects (Fig. 4) (www. eea.europa.eu). During the past 10 years, floods in Europe have killed more than 1000 people and affected 3.4 million others (Jakubicka et al., 2010). Nevertheless, it is difficult to classify which deaths are actually associated with a flood. Immediate flood deaths are best recorded, but deaths during clean-up and longer-term mortality associated with flooding are often not recorded as such (Menne and Murray, 2013).

Recently, Jonkman et al. (2008) provided an in-depth review of current available methods and approaches for the estimation of loss of life due to different types of floods (e.g. for dam breaks, coastal floods, tsunamis), which are normally based on empirical data of historical flood events only, and not physically based. Furthermore, the same authors proposed a new approach to estimate the risk related to the breaching of flood defences in the Netherlands and for similar low-lying areas. Despite being robust and scientifically sound, the method proposed by Jonkman et al. looks very case-specific and rather difficult to apply to a wide range of geomorphological situations and different water-related hazards, as the KR-RRA is intended for.

The proposed KR-RRA approach, in fact, allows the assessment of risks to human health associated with a flood event (i.e. in terms of potential fatalities and injuries), by making the best use of available information at the mesoscale (i.e. CORINE land cover polygons). It focuses on residential areas only, identifying them as major hotspots where people live negleting the presence of people in other areas 
(commercial, industrial, etc.). In particular, the proposed approach is based on the methodology developed by Ramsbottom et al. for the UK Department for Environment, Food and Rural Affairs (DEFRA, 2006). This method was based on a multi-criteria approach to combine different factors that characterize the flood hazard, the chance of people in the floodplain being exposed to the hazard (area vulnerability) and the ability of those affected to respond effectively to flooding (people vulnerability).

\subsubsection{Hazard, exposure and susceptibility assessments}

The flood hazard analysis considers the degree of flood impact on human health according to the specific physical characteristics of an individual (i.e. height, weight, age) and different population typologies (i.e. children, the elderly and those infirm/disabled; adult woman; adult man). The hazard assessment identifies water depth and velocity as relevant physical metrics, which have a direct (linear) relationship with the hazard magnitude (i.e. as water depth and velocity increase, the hazard score increases). Moreover, it is also possible to consider the presence of debris factor (i.e. floating material such as trees, cars, etc.) where it poses a threat to people. The (flood) hazard rate to people is calculated using the following equation (DEFRA, 2006):

$H_{\text {people }}=d \cdot(v+1.5)+D F$,

where $H_{\text {people }}=$ hazard score for people, $d=$ water depth $(\mathrm{m}), v=$ velocity $\left(\mathrm{m} \mathrm{s}^{-1}\right), \mathrm{DF}=$ debris factor $[0 ; 1]$.

Equation (1) allows one to produce an hazard map, where the resolution depends on the outcomes and resolution of the hydraulic modelling and/or the historical data set used to calculate and/or retrieve the physical metrics. DF is scored between 0 (i.e. low probability that debris would lead to a significant hazard) and 1 (i.e. high probability that the debris would lead to a significant hazard), according to different ranges of water depth and flow velocity.

The exposure assessment requires the localization of the people potentially affected by the hazard, which can be defined using census data of population density within the residential areas, as Jonkman (2008) suggested. At any particular time, people may be present in various location (e.g. outdoors, indoors within a multi-storey building) that can be associated with different levels of risk. However, as stated above, the assumption is that all people are present in their homes at low ground, where they do not have access to safe refuge areas. For the sake of simplification, coping capacity during the event (people that are able to evacuate and/or shelter, as well as the solutions implemented by local authorities to manage the emergencies) and adaptive capacity before/after the event (solutions implemented by people and authorities in order to deal with the hazard) are only partially considered by the RRA (see the AV factor in Eq. 3) since these terms are fully enclosed in the subsequent cluster of the
KULTURisk methodology, the SERRA one (see Giupponi et al., 2014).

To characterize the susceptibility, namely the degree to which the people could be affected by the hazard, the KRRRA methodology suggests considering (i) the percentage of resident aged 75 years or over and (ii) the percentage of residents suffering from long-term illness, including disabilities. These conditions are considered as factors that could increase the susceptibility because elderly people can be more prone to health and mobility problems in a flood event and also because many pre-existing medical conditions can increase the probability of health problems related to flooding and of death (e.g. mortality from hypothermia). The susceptibility score (Eq. 2) is therefore calculated by summing these two indicators (DEFRA, 2006):

$\mathrm{SF}_{\text {people }}=\mathrm{sf}_{1}+\mathrm{sf}_{2}$,

where $\mathrm{SF}_{\text {people }}=$ susceptibility score for people $(\%) ; \mathrm{sf}_{1}=\%$ of people over 75 years; $\mathrm{sf}_{2}=\%$ of people with disabilities.

This assessment is based on census data allowing the assigning of a susceptibility score to each census unit (e.g. municipality, census district) and the production of a related map. Indicators and data sources for the assessment of hazard, exposure and susceptibility for people at the meso-scale are reported in Table 7.

\subsubsection{Risk assessment}

The risk assessment produces the spatial characterization of a (relative) risk index to identify and rank areas and hotspots at risk. Hazard (Eq. 1), exposure and susceptibility (Eq. 2) are used within the risk assessment to compute the number of people injured $\left(R_{1}\right)$ and killed $\left(R_{2}\right)$ during a flood event, as follows (DEFRA, 2006):

$$
\begin{aligned}
& R_{1}=2 \cdot E \cdot H_{\text {people }} \cdot \frac{\mathrm{AV}}{100} \cdot \mathrm{SF}_{\text {people }} \\
& R_{2}=2 \cdot R_{1} \cdot \frac{H_{\text {people }}}{100}
\end{aligned}
$$

where $R_{1}=$ number of injuries; $R_{2}=$ number of fatalities; $E=$ exposure (i.e. the number of people that can be potentially directly affected by the flood event); $H_{\text {people }}=$ hazard score to people; $\mathrm{AV}=$ area vulnerability [3;9]; $\mathrm{SF}_{\text {people }}=$ susceptibility score for people $(\%)$.

As per the DEFRA (2006) approach, the area vulnerability AV is defined as the sum of flood warning, speed of onset and nature of the area, ranging from 3 (i.e. gradual onset; area with multi-storey apartments; effective flood warning) to 9 (i.e. no flood warning; rapid flooding; area with mobile homes, busy roads, parks, single storey schools, campsites). Moreover, in order to aggregate the different receptorrelated (relative) risks for the computation of the total risk, a phase of normalization aimed at re-scaling the receptorrelated risk scores into a common closed numerical scale is 
required (Zabeo et al., 2011). The normalization is performed at the CORINE polygon scale, according to the available data set. For the people, the normalization is provided considering the number of injuries/fatalities and the number of people in the highest populated polygon, according to Eqs. (5) and (6):

$$
\begin{aligned}
& R_{1}^{\prime}=\frac{R_{1}}{\text { Number of people in the highest populated polygon }} \\
& R_{2}^{\prime}=\frac{R_{2}}{\text { Number of people in the highest populated polygon }}
\end{aligned}
$$

where $R_{1}^{\prime}=$ normalized risk score for injuries; $R_{2}^{\prime}=$ normalized risk score for fatalities; $R_{1}=$ number of injuries (Eq. 4); $R_{2}=$ number of fatalities (Eq. 5).

This normalization allows one to define risk scores between 0 (i.e. no people injured/dead) and 1 (i.e. all the people living in the highest populated polygon are injured/killed).

\subsection{Physical/environmental risk assessment for economic activities}

To fulfil the requirements of the FD, the flood risk assessment related to economic activities has considered three relevant sub-receptors: buildings, infrastructure and agriculture.

\subsubsection{Physical/environmental risk assessment for buildings}

Floods have a potential massive impact on buildings (e.g. to the structures and to the indoor goods), particularly in highly populated areas, corresponding to residential and commercial-industrial sites, triggering severe (socio-) economic consequences.

Papathoma-Kohle et al. (2011) and Fuchs et al. (2012) recently provided insight into the current approaches and future needs of vulnerability assessment of buildings, when affected by water-related natural hazards. The most popular approach concerned the use of (empirical) stage-damage functions that linked inundation depth to expected losses, that is reliable method for still (static) waters but do not consider the impact of flowing (dynamic) waters to the structures as a relevant indicator (Büchele et al., 2006). Generally speaking, the authors mentioned above remarked on the lack of multidimensional approaches, and outlined some key issues that need to be addressed by an ultimate risk assessment methodology. It is worth noticing that some of these issues have been addressed by the KR-RRA, in particular as far as the involvement of end users, transferability of methods, spatial approach (GIS based) and hazard dependency are concerned. Finally, in the proposed KR-RRA the receptor buildings has been characterized by its footprint in the area as well as by its economic use, according to the CORINE land cover classes of industrial and residential areas. At meso-scale level, this classification allows one to define the percentage and the typology of buildings affected by a flood event with different degrees of structural damage.

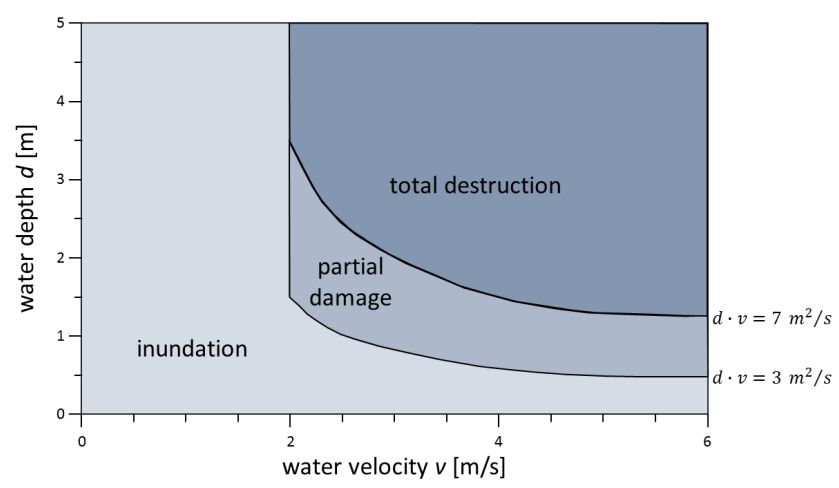

Figure 5. Identification of risk classes for different values of flow intensity for buildings (from Clausen and Clark, 1990).

\section{Hazard, exposure and susceptibility assessments}

The above-mentioned methods for vulnerability assessment of buildings are characterized by a consistent use of sophisticated physical approaches and screening methods, only applicable at the very local scale (micro-zonation). For example, they consider the damage related to different building typologies, as suggested by Schwarz and Maiwald (2008), the material construction and its quality, the building level, the state of conservation, contamination and precautionary principles (Büchele et al., 2006; Mebarki et al., 2012; Totschnig and Fuchs, 2013). Without excluding the possibility of future refinement and enhancement of the KR-RRA method by matching the level of detail and data availability required with the necessary portability of the tool, some simplifications and assumptions have been considered in order to fully apply the methodology at the regional (meso-scale) level, in particular as far as the susceptibility assessment is concerned.

Within the proposed KR-RRA, reference is made to the approach proposed by Clausen and Clark (1990) where, by assuming that all the buildings are characterized by the same structure, different magnitudes of potential structural damage have been identified and related to the flood intensity (Fig. 5).

\section{Risk assessment}

Based on the approach proposed by Clausen and Clark (1990), the methodology allows one to calculate the number (and percentage) of buildings affected by floods, according to different risk classes (see Table 1). This method provides three risk classes (i.e. inundation, partial damage, and total destruction), based on specific thresholds for the flow velocity and for the product between water depth and flow velocity (defined as intensity). The risk assessment for buildings $\left(R_{3}\right)$ allows the estimation of the number, coverage $\left(\mathrm{km}^{2}\right)$ and the percentage of flooded buildings belonging to different uses (i.e. CORINE land cover polygons related to residential and commercial-industrial areas) in each risk class, in the form of tables (summarizing the statistics) and 
Table 1. Identification of the building-related risk classes according to specific thresholds for different values and combination of water depth $(d)$ and water velocity $(v)$, as proposed by Clausen and Clark (1990).

\begin{tabular}{lll}
\hline $\begin{array}{l}\text { Flood hazard } \\
\text { threshold }\end{array}$ & $\begin{array}{l}\text { Building-related } \\
\text { risk classes }\left(R_{3}\right)\end{array}$ & Definition \\
\hline$v \leq 2$ or $v d \leq 3$ & Inundation & $\begin{array}{l}\text { Damage similar to that caused by a natu- } \\
\text { ral low-velocity river flood. No immediate } \\
\text { structural damage }\end{array}$ \\
\hline$v>2$ and $3<v d \leq 7$ & Partial damage & $\begin{array}{l}\text { Moderate structural damage, i.e. windows } \\
\text { and doors knocked out. Little damage to the } \\
\text { major structural elements of the building }\end{array}$ \\
\hline Otherwise & Total destruction & $\begin{array}{l}\text { Total structural collapse or major damage to } \\
\text { the structure necessitating demolition and re- } \\
\text { building }\end{array}$ \\
\hline
\end{tabular}

Table 2. Physical/environmental risk classes and normalized scores for buildings.

\begin{tabular}{lr}
\hline Classes & $\begin{array}{r}\text { Normalized } \\
\text { scores }\end{array}$ \\
\hline Not inundated & 0 \\
Inundated & 0.2 \\
Partial damage & 0.6 \\
Total destruction & 1 \\
\hline
\end{tabular}

maps (highlighting the areas at different risks). Finally, a normalization aimed at re-scaling the receptor-related risk scores into a common numerical scale (0-1) is performed (Zabeo et al., 2011) according to the scores proposed in Table 2 that have been defined by the authors using a dedicated qualitative evaluation. Of course, different scores based on site-specific knowledge, literature data and expert judgement can be assigned during the application of the proposed methodology.

\subsubsection{Physical/environmental risk assessment for infrastructure}

Floods affect infrastructure networks, causing loss of services (e.g. unpassable roads and railways, interruption of power supply, etc.) in addition to structural direct damage (e.g. damage to roads, bridges, destruction of power stations, etc.). Studies of past flood events have shown that the majority of losses arise in urban areas, due to damage/weakening of structures, the costs of business shutting down and failure of infrastructure (EEA, 2010; ADBI, 2010). Evacuations, property damage and infrastructure closures are among the challenges faced by those operating in a wide range of industries, including manufacturing, retail, transport, agriculture and tourism. A very recent example comes from the severe flooding experienced in central/eastern Europe in June 2013 that led to significant damage to infrastructure-related businesses.

According to the Flood Directive (2007/60/EC), the KRRRA methodology allows one to identify roads and railways affected by flooding, by considering only the inundation of the infrastructure as the main impact of interest. In fact, for the sake of simplification, only the loss of services for the network of infrastructures during and afer the event is assessed, without considering any structural damage related to the flood event (damage and/or collapse of roads, bridges, railways, etc.).

\section{Hazard, exposure and susceptibility assessments}

Based on these premises, the hazard assessment considers the flood extension (inundated area) as the metric of reference. Water depth and its lower boundary values are not considered because of the scale of analysis and lack of specific literature on this topic. However, if data and research were available, the characterization of the functionality of (transport) infrastructure could be reasonably performed. The exposure assessment focuses on the spatial localization and distribution of the roads, railways and pathways. These objects are geometrically characterized by their linear extension (length) rather than by their surface extension (area). Finally, the susceptibility assessment assigns the same score to the whole set of assets (e.g. roads, highways, railroads). As for the buildings, at the micro-scale level the physical susceptibility assessment could be further improved by considering the construction typology, functions and dimensions of the considered infrastructure.

\section{Risk assessment}

Accordingly, the infrastructure-related risk $\left(R_{4}\right)$ is calculated from the intersection of the inundation map with the road and railway atlas in order to identify and characterize the infrastructure inundated by the flood event. In this case, the physical/environmental assessment results in the estimation 
Table 3. Thresholds for flood hazard metrics for different agricultural typologies, in the spring, summer and autumn seasons (adapted from Citeau, 2003).

\begin{tabular}{lrr}
\hline $\begin{array}{l}\text { Agricultural } \\
\text { typologies }\end{array}$ & $\begin{array}{r}\text { Maximum water } \\
\text { depth }[\mathrm{m}]\end{array}$ & $\begin{array}{r}\text { Maximum water } \\
\text { velocity }\left[\mathrm{m} \mathrm{s}^{-1}\right]\end{array}$ \\
\hline Vegetables & - & $0.25 \mathrm{~m} \mathrm{~s}^{-1}$ \\
Vineyards & $0.5 \mathrm{~m}$ & $0.25 \mathrm{~m} \mathrm{~s}^{-1}$ \\
Fruit trees & $1 \mathrm{~m}$ & $0.5 \mathrm{~m} \mathrm{~s}^{-1}$ \\
and olive groves & & \\
\hline
\end{tabular}

of the length $(\mathrm{km})$ and the percentage of infrastructure potentially affected by flood in each CORINE land cover polygon, in the form of tables (summarizing the statistics) and maps (highlighting the areas at risk). Again, this step requires a phase of normalization aimed at re-scaling the receptorrelated risk scores into a common numerical scale $(0-1)$ (Zabeo et al., 2011). For infrastructure, the normalization is performed considering the length of flooded items in each polygon and the total length within the same polygon, as in Eq. (7):

$R_{4}^{\prime}=\frac{R_{4}}{\text { Total length of infrastructure in the same polygon }}$,

where $R_{4}^{\prime}=$ normalized risk score for infrastructure; $R_{4}=$ length of flooded infrastructure in each polygon.

The assumption is that if in a polygon all the infrastructure was flooded, people cannot secure their health and their property (i.e. all evacuation routes are inaccessible) so the risk is maximum.

\subsubsection{Physical/environmental risk assessment for agriculture}

Floods can damage crops that become oversaturated, but they can also cause damage to farmland and infrastructure. These impacts can lead to economic damage both direct and indirect (e.g. loss of agricultural soil due to erosion, scarcity of cereals, etc.) with only few methodological approaches available for their (monetary) quantification (Dutta et al., 2003; Meyer et al., 2009). Recent events in the province of Modena (northern Italy) confirmed the relevance of this receptor within the (socio-) economic compartment with EUR 54 M of losses caused by (only) 2 days of rainfall in late January 2014 (ANSA, 2014). The KR-RRA approach is aimed at mapping potential flood risk to agriculture by means of ready-available data at the meso-scale level (i.e. CORINE land cover polygons of the agricultural areas) to spatially characterize the pattern of relevant crops. Specifically, the aim of the RRA methodology for agriculture is to define the percentage of harvest loss due to a flood event, without any consideration of the damage to agricultural buildings since these have been already considered along with the assessment for economic activities, see Sect. 2.5.1.
Table 4. Risk classes and normalized scores for agriculture.

\begin{tabular}{llr}
\hline Risk classes & Description & $\begin{array}{r}\text { Normalized } \\
\text { scores }\end{array}$ \\
\hline Not inundated & No flood & 0 \\
Inundated & $\begin{array}{l}\text { Flood metrics values } \\
\text { are below the thresholds }\end{array}$ & 0.6 \\
Total destruction & $\begin{array}{l}\text { Flood metrics values } \\
\text { are over the thresholds }\end{array}$ & 1 \\
\hline
\end{tabular}

\section{Hazard, exposure and susceptibility assessments}

Based on the analysis proposed by Citeau (2003) supported by bibliographic data and in situ surveys, the proposed assessment requires the identification of water depth and velocity as relevant physical metrics to characterize the hazard. The exposure assessment allows the localization of the different agricultural typologies considered (i.e. vegetables, vineyards, fruit trees and olive groves) in the case study area, according to the land use pattern provided by the data set of reference. For the vulnerability, a set of flood metrics thresholds for the have been established to characterize the different agricultural typologies (see Table 3), also according to the seasonality factor. For example, vegetables are more susceptible than fruit trees to inundation phenomena, therefore their threshold for the flow velocity is lower for the former. Nevertheless, updated and site-specific thresholds can be established, when available, together with other relevant factors (e.g. water stagnation) to better characterize the susceptibility assessment.

\section{Risk assessment}

Giving the hazard thresholds provided by Table 3, within the risk assessment phase it is possible to identify the agricultural area inundated (i.e. if the flood hazard values are below the identified thresholds) or loss (i.e. if the flood hazard values exceed the thresholds) and therefore to calculate the total flooded agricultural area $\left(\mathrm{km}^{2}\right)$ and the percentage of crop typologies affected, in the form of tables (summarizing statistics) and maps (highlighting the areas at different risk levels). Specifically, the agriculture-related risk $\left(R_{5}\right)$ is calculated for spring, summer and autumn seasons by assuming that during the wintertime there are no crops exposed to the impact of flood. For this season, it is only possible to distinguish between inundated and not inundated agricultural areas. Finally, the normalization phase provides values between 0 and 1, according to the authors' evaluation, as summarized in Table 4. However, local stakeholders and others can assign different scores based on site-specific knowledge, literature data and expert judgement. 
Table 5. Qualitative evaluations supporting the expert in the assigning of relative scores to susceptibility and risk classes.

\begin{tabular}{lr}
\hline Linguistic Evaluation & Score \\
\hline Most important class & 1 \\
Slightly less important class & 0.8 \\
Rather less important class & 0.6 \\
Strongly less important class & 0.4 \\
Least important class & 0.2 \\
No susceptibility & 0 \\
\hline
\end{tabular}

\subsection{Physical/environmental risk assessment for natural and semi-natural systems}

Floods tend to degrade natural systems (i.e. natural and seminatural ecosystems, protected areas, wetlands) by destroying vegetation, degrading hillslopes and river beds, altering the pattern of erosion/sedimentation processes and transferring both sediment and nutrients. Other negative effects include loss of habitat, dispersal of weed species, release of pollutants, lower fish production and loss of recreational areas. Accordingly, the aim of the proposed KR-RRA methodology is to characterize the degree to which natural systems can be affected by a flood event due to their pattern of (physical) peculiarities causing a permanent, or temporal, loss of ecosystems services.

\subsubsection{Hazard, exposure and susceptibility assessments}

Flood extension area $\left(\mathrm{km}^{2}\right)$ has been selected as relevant physical metric to characterize the impact on natural and semi-natural systems. Moreover, the exposure assessment allows localizing the receptor by considering the CORINE land cover classes related to forest, semi-natural areas and wetlands. As far as the susceptibility assessment is concerned, following Pasini et al. (2012), a series of indicators have been selected to characterize the physical characteristics of the analysed territory reflecting variations in the degree to which the natural and semi-natural systems may be affected by a flood event. These indicators are as follows:

- Vegetation cover

- Slope

- Wetland extension

- Soil type

Each susceptibility indicator is classified and scored through expert elicitation. For vegetation cover, for example, susceptibility classes are defined by considering different land cover typologies such as grass, shrub and forest. Specifically, the susceptibility of soil to floods increases when vegetative cover and slopes decreases. In fact, when it comes to loss of biodiversity and ecological value, especially in the medium
Table 6. Classification and ranking of hazard scores for natural and semi-natural systems.

\begin{tabular}{lr}
\hline Classes & $\begin{array}{r}\text { Normalized } \\
\text { scores }\end{array}$ \\
\hline Not inundated & 0 \\
Low & 0.2 \\
Medium & 0.6 \\
High & 1 \\
\hline
\end{tabular}

to long term, environments characterized by lower slopes are more susceptible to floods since they are subject to water stagnation and therefore soil degradation, while steeper slopes are less susceptible as they facilitate water drainage (Preston et al., 2008). The same applies for the soil type indicator, where classes and thresholds are established considering that the more waterproof soil type typologies are the most susceptible to flooding because they cannot drain the standing waters (Yahaya et al., 2010). Moreover, higher susceptibility scores have been assigned to wetlands with lower surface areas, which may be more sensitive to flood pressures than wider ones (Torresan et al., 2012). The relative classification of these factors is performed by using the equal interval classification (Zald et al., 2006).

Once susceptibility classes are defined, the assigning of the (relative) scores to classify their (relative) importance in the analysed area is performed by experts and local stakeholders following the linguistic evaluations reported in Table 5 .

Finally, the susceptibility indicators are aggregated through a MCDA function named "Probabilistic Or" (Kalbfleisch, 1985), which provides a single normalized score of susceptibility for homogeneous areas, as follows:

$S_{\text {nat }}=\otimes_{i}^{n}\left[\mathrm{sf}_{i}^{\prime}\right]$

where $S_{\text {nat }}=$ susceptibility score of the cell; $\otimes=$ "Probabilistic Or" function; $\mathrm{sf}_{i}^{\prime}=i$ th susceptibility factor score (classified in $[0,1]$ ).

When applying the Eq. (8), if just one susceptibility factor (sf) assumes the maximum value (i.e. 1), then the susceptibility score will be 1 . On the other hand, sf with low scores contribute to increasing the final susceptibility score: the higher the number of low susceptibility factor scores, the greater the final susceptibility (details in Appendix A).

\subsubsection{Risk assessment}

Finally, hazard and susceptibility scores are aggregated into a relative risk score $\left(R_{6}\right)$ as follows:

$R_{6}=H_{\text {nat }} \cdot S_{\text {nat }}$

where $R_{6}=$ risk related to natural and semi-natural systems; $H_{\text {nat }}=$ hazard score (according to Table 6); 
Table 7. Characterization of data used for the three phases of assessment, according to the physical/environmental KR-RRA approach, for the selected receptors (P: people; B: buildings; I: infrastructure; A: agriculture; NS: natural and semi-natural systems; $\mathrm{CH}$ : cultural heritage).

\begin{tabular}{|c|c|c|c|}
\hline $\begin{array}{l}\text { Steps of the physical/ } \\
\text { environmental RRA }\end{array}$ & Indicators/metrics & Data sources & Receptors \\
\hline \multirow[t]{4}{*}{ Hazard } & Water depth & Flood modelling & $P-B-A$ \\
\hline & Water velocity & Flood modelling & $\mathrm{P}-\mathrm{B}-\mathrm{A}$ \\
\hline & Flood extension & Flood modelling and mapping & $\mathrm{I}-\mathrm{A}-\mathrm{NS}-\mathrm{CH}$ \\
\hline & Debris factor & land cover map & $\mathrm{P}$ \\
\hline \multirow[t]{6}{*}{ Exposure } & Presence of people in residential areas & $\begin{array}{l}\text { Census data, land cover/land } \\
\text { use map }\end{array}$ & $\mathrm{P}$ \\
\hline & Presence of buildings & Land cover/land use map & $\mathrm{B}$ \\
\hline & Presence of infrastructure & Road and railway atlas & I \\
\hline & Presence of agricultural typologies & Land cover/land use map & A \\
\hline & Natural and semi-natural systems & $\begin{array}{l}\text { Land cover/land use map, pro- } \\
\text { tected area map }\end{array}$ & NS \\
\hline & Presence of cultural heritage & $\begin{array}{l}\text { Regional technical map, UN- } \\
\text { ESCO cultural heritage map }\end{array}$ & $\mathrm{CH}$ \\
\hline \multirow[t]{5}{*}{ Susceptibility } & $\begin{array}{l}\text { People over } 75 \text { years and } \\
\text { infirm/disabled/long-term sick }\end{array}$ & Census data & $\mathrm{P}$ \\
\hline & Vegetation cover & Land cover/land use map & NS \\
\hline & Slope & $\begin{array}{l}\text { Digital elevation model } \\
\text { (DEM) }\end{array}$ & NS \\
\hline & Soil type & Geomorphologic/soil map & NS \\
\hline & Wetland extension & Land cover/land use map & NS \\
\hline
\end{tabular}

$S_{\text {nat }}=$ susceptibility score calculated according to the "Probabilistic Or" function (Eq. 8).

The results of the risk assessment for this receptor are gridbased layers where cells are ranked in different risk classes (e.g. low, medium, high) with tables summarizing the statistics and maps, highlighting the areas at risk. As for the other receptors, a phase of normalization aimed at re-scaling the qualitative risk classes (i.e. low, medium, high) is performed.

\subsection{Physical/environmental risk assessment for cultural heritage}

Flooding can damage architectural heritage, historic buildings, sites and cultural assets in general. The case of the city of Florence in 1966 is emblematic, when thousands of students and volunteers from all over the world rushed in Italy to support the saving of the inestimable artistic heritage threatened by the muddy waters of the Arno river. Cultural assets are subjected to various forces (e.g. static or hydrostatic pressure, flow velocity and waves) and actions during flood situations ( Drdácký, 2010; Nedvědová and Pergl, 2013). According to the Flood Directive (2007/60/EC) which requires the localization of the potential cultural heritage affected by floods, the KULTURisk-RRA method includes cultural heritage as a relevant receptor for the integrated flood risk assessment.

\subsubsection{Hazard, exposure and susceptibility assessments}

It is worth specifying that the analysis of risk at meso-scale level is not oriented to the evaluation of structural damage to cultural assets but only to the identification of affected (flooded) items. Therefore, flood extension area $\left(\mathrm{km}^{2}\right)$ is identified as relevant physical metric to characterize the hazard. The UNESCO World Heritage Convention (1972) distinguishes three different typologies of cultural heritage: monuments (which are of outstanding value from the point of view of history, art or science), groups of buildings (separate or connected) and sites (which are of outstanding universal value from the historical, aesthetic, ethnological or anthropological points of view). Spatially they can be considered as points (i.e. monuments) and areas (i.e. buildings and sites) overlapping with the polygons of CORINE land cover.

Starting from the available information at the meso-scale (i.e. location and typology of cultural heritage) and assuming that the cultural assets are affected in the same way by the flood, the susceptibility assessment assigns an equal score for the entire suite of items, separately or attached as an integral group of buildings.

\subsubsection{Risk assessment}

The risk assessment for the cultural heritage aims to provide the number of flooded monuments, the coverage $\left(\mathrm{km}^{2}\right)$ and percentage of inundated cultural buildings and archae- 
Table 8. Risk classes score definition used to characterize the total risk index (GIS equal interval classification).

\begin{tabular}{lr}
\hline Risk Classes & Score \\
\hline Not at risk & 0 \\
Very low & $0-0.2$ \\
Low & $0.2-0.4$ \\
Medium & $0.4-0.6$ \\
High & $0.6-0.8$ \\
Very high & $0.8-1$ \\
\hline
\end{tabular}

ological/historical sites in the form of tables (summarizing the statistics) and maps (highlighting the cultural heritage at risk). Accordingly, the cultural heritage-related risk for single monuments $\left(R_{7}\right)$ and sites $\left(R_{8}\right)$ are calculated from the intersection between the flood extension map and the cultural heritage map.

For this receptor, the normalization phase is performed by considering the number of inundated monuments in each CORINE land cover polygon and the totality of assets lying in the polygon most populated by cultural objects (Eq. 10). For coverage, the cultural sites flooded area $\left(\mathrm{km}^{2}\right)$ in each CORINE land cover polygon and the total area $\left(\mathrm{km}^{2}\right)$ of cultural sites in the polygon more extensively covered by cultural assets (Eq. 11), are considered.

$$
R_{7}^{\prime}=\frac{R_{7}}{\begin{array}{l}
\text { total number of monuments of the polygon } \\
\text { with the highest number of monuments }
\end{array}}
$$

where $R_{7}^{\prime}=$ normalized risk score for cultural heritage (monuments); $R_{7}=$ number of flooded monuments in each polygon.

$$
R_{8}^{\prime}=\frac{R_{8}}{\begin{array}{l}
\text { coverage of cultural sites }\left[\mathrm{km}^{2}\right] \text { in the polygon with } \\
\text { the largest cultural site area }
\end{array}},
$$

where $R_{8}^{\prime}=$ normalized risk score for cultural heritage (sites); $R_{8}=$ cultural sites flooded area $\left(\mathrm{km}^{2}\right)$, in each polygon.

Again, if more detailed information related to the cultural heritage (e.g. site-specific surveys and archives) were available, a deeper analysis at the micro-scale (structural damage) could be performed by considering further physical susceptibility indicators, such as the material construction, the state of conservation, etc.

\subsection{Total risk index}

The (very) final result of the KR-RRA methodology is a GIS-based total risk map which allows one to identify and rank areas and hotspots at risk across the examinated region. Total risk index is calculated by aggregating different receptor-related risks by means of MCDA method. The field of MCDA encompasses different methodologies aimed at integrating heterogeneous criteria and decision maker insight towards the selection of plausible alternatives. Outranking methods and multi-attribute value theory (MAVT) are the most popular approaches in MCDA. The first ones, based on direct comparisons, have been discarded because of the complex and time-consuming inputs required from users (Vincke, 1992). Instead, MAVT methodology has been selected which allows a sound ranking with relatively low user requirements (Giove et al., 2009).

The KR-RRA methodology uses the weighted average (Eq. 12) as an effective method of aggregation, which is useful in liner additive contexts only, where receptors' risk are considered to be linearly additive and neither synergic nor redundant effects among risks and indicators are present.

$$
R_{\mathrm{tot}}=\frac{\sum_{\forall r} w_{\mathrm{r}} R_{\mathrm{r}}^{\prime}}{\sum_{\forall r} w_{\mathrm{r}}}
$$

where $R_{\mathrm{tot}}=$ total risk; $w_{\mathrm{r}}=$ weight associated with the $\mathrm{r}$ receptor-related risk $[0,1] ; R_{\mathrm{r}}^{\prime}=$ normalized risk score associated with the r-receptor-related risk.

The assignment of weights is performed by expert and local stakeholder consultation. The ranking process is supposed to give priority to those whose flooding damaging consequences are considered as burdensome. In this sense, weighting is a typical political decision-making process and the involvement of relevant stakeholders is seen as a fundamental prerequisite for its effectiveness (Yosie and Herbst, 1998).

The final output is a total risk map (with risk scores between 0 and 1) where classes have been defined using the equal interval GIS tool (see Table 8). Risk scores are not absolute predictions about the risks related to floods, rather they provide relative classifications about areas and targets that are likely to be affected by these events more severely than others within the same region. By facilitating the localization of hotspots at risk, such as hospitals, schools, harbours, railway stations, airports, protected areas, potential pollution-causing installations, the total risk maps support decision makers and local stakeholders work towards knowledge-based disaster management, as well as the planning of mitigation measures and sustainable land use. On the other side, receptor-related risk maps should be used when a more specific and detailed analysis of the risk pattern that characterize the various elements at risk is needed.

\section{Conclusions}

The paper proposes a state-of-the-art methodology, based on the Regional Risk Assessment approach and shaped in the legislative framework established by the European Flood Directive, for the integrated assessment of water-related hazards at the regional scale (i.e. meso-scale) for multiple receptors/elements at risk (i.e. people, economic activities, natu- 
ral and semi-natural systems and cultural heritage). For each of the selected receptors/elements at risk and by making a considerable use of GIS tools, the methodology proposes a specific procedure for the estimation of a (normalized and spatially distributed) relative risk index through multi-layer analysis, based on the subsequent assessment of hazards, exposure and vulnerability patterns. Together with the GISbased maps, the outcomes of the application are indicators and statistics that quantify the risk for the considered receptors (e.g. number of people at risk, coverage of flooded infrastructure at higher risk, percentage of residential buildings and commercial buildings at risk, extension of flooded agricultural lands, etc.). Finally, the total risk index is calculated by aggregating the different receptor-related risks by means of MCDA through expert and local stakeholder elicitation. The KR-RRA methodology should not attempt to provide absolute predictions about flood impacts. Rather, this instrument supports the ranking of area, sub-areas and hotspots that are more vulnerable and possibly more strongly affected by flood events within the investigated region in order to evaluate the benefits of different risk prevention scenarios (i.e. baseline and alternative scenarios) where structural and/or non-structural measures are implemented. With the ultimate aim of underpinning risk prevention measures and share with decision makers and stakeholders the potential implications of floods (in non-monetary terms), the proposed KR-RRA methodology demonstrates that prevention is accountable and its benefits are measurable. In fact, it facilitates the quantification, in physical terms, of the risk avoidance related to the implementation of the (proposed) prevention measures and considered by the different scenarios and settings. On this basis, investments in prevention by public administrations can be better evaluated and shared with citizens, also in order to support the establishment of a culture of prevention across the whole of society. The proposed methodology represents an scientifically sound instrument towards the implementation of the Flood Directive in different environments and contexts. Its flexibility really allows its application to different case studies (i.e. plain rivers, mountain torrents, urban areas and coastal areas) and spatial scales (i.e. from the river basin to the urban scale), to individuate particular criticisms in flood-prone areas at the meso-scale: the implementation of the Flood Directive at the micro-scale inevitably requires a more detailed analysis. Moreover, it is undeniable that a further limitation of this methodology consists in its (relatively high) degree of (political) subjectivity when assigning weights and scores by means of experts elicitation. On the other hand, as per the 2014 IPCC AR5 report, the expert judgement (using specific criteria) must be used to "integrate the diverse information sources relating to the severity of consequences and the likelihood of occurrence into a risk evaluation, considering exposure and vulnerability in the context of specific hazards" in order to cope with the fact that "data are seldom sufficient to allow direct estimation of probabilities of a given outcome" (IPCC, 2014).
Furthermore, the methodology can be further improved by taking into consideration the complex dynamics of feedbacks between physical, social and political factors that relevant end-users, decision makers and local experts frequently pose (see the companion paper, Part 2, Ronco et al., 2014). In this sense, the characterization of the vulnerability patterns for (selected) communities and areas through the combination of different drivers, such as collective memory, risk-taking attitudes and trust in protection measures, as proposed by Viglione et al. (2014), or by considering its temporal evolution as proposed by Mazzorana et al. (2012), represent a new, challenging, frontier for the next generation of risk assessment methodologies. In a rapidly changing world, risk changes significantly across time, space and culture. Finally, in order to propose a harmonized overall approach to risk assessment, both the suitability and applicability of the overall KULTURisk methodological approach to other types of hazards (earthquakes, forest fires, etc.) could be analysed in detail, through the involvement of a number of experts in these fields.

\section{Appendix A: Mathematical background}

The "Probabilistic Or" function (Kalbfleisch, 1985) is expressed as

$\otimes_{i=1}^{4}\left[f_{i}\right]=f_{1} \otimes f_{2} \otimes f_{3} \otimes f_{4}$

where $f_{i}=i$ th generic factor $f$.

Due to the associative and commutative proprieties, the "Probabilistic Or" operator can be evaluated as follows:

$$
\begin{aligned}
& f_{1} \otimes f_{2}=f_{1}+f_{2}-f_{1} f_{2}=F_{1}, \\
& F_{1} \otimes f_{3}=F_{1}+f_{3}-F_{1} f_{3}=F_{2}, \\
& F_{2} \otimes f_{4}=F_{2}+f_{4}-F_{2} f_{4}=\otimes_{i=1}^{4}\left[f_{i} .\right]
\end{aligned}
$$

The process can be repeated until evaluating all operands.

If just a factor $(f)$ assumes the maximum value (i.e. 1), then the result of the "Probabilistic Or" will be 1 . On the other hand, $f$ with low scores contribute to increasing the final "Probabilistic Or" score: the higher the number of low factor scores, the greater the final score.

Acknowledgements. This work was found by the Seventh Framework Programme (FP7) of the European Commission within the collaborative project "Knowledge-based approach to develop a culture of risk prevention (KULTURisk)", FP7-ENV-2010, project 265280; www.kulturisk.eu. The authors wish to kindly acknowledge the editor and two anonymous referees for their constructive suggestions which improved earlier versions of this manuscript.

Edited by: G. Di Baldassarre 


\section{References}

ADBI: Asian Development Bank Institute and The World Bank: Pakistan floods 2010: Preliminary damage and needs assessment, Asian Development Bank, Islamabad, 2010.

Annamo E. and Kristiansen, G.: Challenges in Flood Risk Management Planning. An example of a Flood Risk Management Plan for the Finnish-Norwegian River Tana, Norwegian Water Resources and Energy Directorate, Oslo, ISSN:1501-2832, Report no. 16, 2012.

ANSA: $54 \mathrm{mln}$ danni da alluvione a agricoltura, available at: https://www.ansa.it/web/notizie/rubriche/cronaca/2014/ 02/03/54-mln-danni-alluvione-agricoltura_10008712.html (last access: 3 February 2014), 2014 (in Italian).

Balica, S. F., Douben, N., and Wright, N. G.: Flood vulnerability indices at varying spatial scales, Water Sci. Technol., 60, 25712580, 2009.

Barredo, J. I.: Major flood disasters in Europe: 1950-2005, Nat. Hazards, 42, 125-148, 2007.

Bates, B. C., Kundzewicz, Z. W., Wu, S., and Palutikof, J. P.: Climate Change and Water: IPCC Technical Paper IV, Intergovernmental Panel on Climate Change, IPCC Secretariat, Geneva, 2008.

Büchele, B., Kreibich, H., Kron, A., Thieken, A., Ihringer, J., Oberle, P., Merz, B., and Nestmann, F.: Flood-risk mapping: contributions towards an enhanced assessment of extreme events and associated risks, Nat. Hazards Earth Syst. Sci., 6, 485-503, doi:10.5194/nhess-6-485-2006, 2006.

Cirella, G. T., Semenzin, E., Critto, A., and Marcomini, A.: Natural hazard risk assessment and management methodologies review: Europe, in: Sustainable Cities and Military Installations: Climate Change Impacts on Energy and Environmental Security, edited by: Linkov, I., Springer, the Netherlands, 329-358, 2014

Citeau, J. M.: A New Control Concept in the Oise Catchment Area, Definition and Assessment of Flood Compatible Agricultural Activities, FIG working week, Paris, France, 2003.

Clausen, L. and Clark, P. B.: The development of criteria for predicting dam break flood damages using modelling of historical dam failures, in: International Conference on River Flood Hydraulics, edited by: White, W. R., Hydraulics Research Limited, John Wiley \& Sons Ltd., Wallingford, UK, 369-380, 1990.

DEFRA: Flood Risk to People Phase 2, FD2321/TR2 Guidance Document, Department for Environment, Food and Rural Affairs, London, UK, March 2006.

Di Baldassarre G., Castellarin, A., Montanari, A., and Brath, A.: Probability weighted hazard maps for comparing different flood risk management strategies: a case study, Nat. Hazards, 50, 479496, 2009.

Di Baldassarre, G., Schumann, G., Bates, P. D., Freer, J., and Beven, K.: Floodplain mapping: a critical discussion on deterministic and probabilistic approaches, Hydrol. Sci. J., 55, 364-376, 2010.

Directive 2007/60/EC: On the Assessment and Management of Flood Risks, The European Parliament and of the Council of 23 October 2007, Brussels, Belgium, 2007.

Drdácký, M.: Impact of floods on heritage structures, J. Perform. Facil. 24, 430-431, 2010.

Dutta, D., Herath, S., and Musiake, K.: A mathematical model for flood loss estimation, J. Hydrol., 277, 24-49, 2003.
EEA: European Environment Agency: CLC2006 technical guidelines, Publications Office of the European Union, Luxembourg, 2007.

EEA: European Environment Agency: Mapping the impacts of natural hazards and technological accidents in Europe - an overview of the last decade, Luxembourg: Publications Office of the European Union, 2010.

EEA: European Environment Agency: Water resources in Europe in the context of vulnerability" Luxembourg: Publications Office of the European Union, 2012.

Förster, S., Kuhlmann, B., Lindenschmidt, K.-E., and Bronstert, A.: Assessing flood risk for a rural detention area, Nat. Hazards Earth Syst. Sci., 8, 311-322, doi:10.5194/nhess-8-311-2008, 2008.

Forte, F., Pennetta, L., and Strobl, R. O.: Historic records and GIS applications for flood risk analysis in the Salento peninsula (southern Italy), Nat. Hazards Earth Syst. Sci., 5, 833-844, doi:10.5194/nhess-5-833-2005, 2005.

Fuchs, S., Birkmann J., and Glade, T.: Vulnerability assessment in natural hazards and risk analysis: current approaches and future challenges, Nat. Hazards, 64, 1969-1975, 2012.

Giove, S., Brancia, A., Satterstrom, F. K., and Linkov, I.: Decision Support Systems and Environment: Role of MCDA. In Decision Support Systems for Risk Based Management of Contaminated Sites, Springer Verlag, New York, 2009.

Giupponi, C., Mojtahed, V., Gain, A. K., Biscaro, C., and Balbi, S.: Integrated Risk Assessment of Water Related Disasters, in: Paron, P. and Di Baldassarre, G., Hydro-Meteorological Hazards, Risks, and Disasters, Elsevier, 163-200, 2014.

Hewitt, K.: Regions of risk. A geographical introduction to disasters, Longman, Ltd. Essex, UK, 1997.

Hirabayashi, Y., Mahendran, R., Koirala, S., Konoshima, L., Yamazaki, D., Watanabe, S., Kim, H., and Kanae, S.: Global flood risk under climate, Nat. Clim. Change, 3, 816-831, 2013.

Hunsaker, C. T., Graham, R. L., Suter II, G. W., O’Neill, R. V., Barnthouse, L. W., and Gardner R. H.: Assessing ecological risk on a regional scale, Environ. Manage., 14, 325-332, 2010.

Hufschmidt, G. and Glade, T.: Vulnerability analysis in geomorphic risk assessment, edited by: Alcantara-Ayala, I. and Goudie, A., Geomorphological hazards and disaster prevention, Cambridge University Press, Cambridge, 233-243, 2010.

IPCC: Intergovernmental Panel on Climate Change: Managing the Risks of Extreme Events and Disasters to Advance Climate Change Adaptation. A Special Report of Working Groups I and II of the Intergovernmental Panel on Climate Change, Cambridge University Press, Cambridge, UK, and New York, NY, USA, 582 pp. 2012.

IPCC: Intergovernmental Panel on Climate Change: Synthesis Report (SYR) of the IPCC Fifth Assessment Report (AR5), 116 pp., released online in unedited form, 2014.

ISPRA: Istituto Superiore per la Protezione e la Ricerca Ambientale: Proposta metodologica per l'aggiornamento delle mappe di pericolosità e di rischio. Attuazione della Direttiva 2007/60/EC relativa alla valutazione e alla gestione dei rischi da alluvioni Decreto Legislativo n. 49/2010, Rome, Italy, 2012.

Jakubicka, T., Vos, F., Phalkey, R., and Marx, M.: Health impacts of floods in Europe: data gaps and information needs from a spatial perspective, a MICRODIS report, Brussels, Centre for Research on the Epidemiology of Disasters, 2010. 
Jonkman, S. N., Vrijling, J. K., and Vrouwenvelder, A. C. W. M.: Methods for the estimation of loss of life due to floods: a literature review and a proposal for a new method, Nat. Hazards, 46, 353-389, 2008.

Kalbfleisch, J. G.: Probability and Statistical Inference: Volume 1: Probability, Springer Texts in Statistics, the Netherlands, 1985.

Kubal, C., Haase, D., Meyer, V., and Scheuer, S.: Integrated urban flood risk assessment - adapting a multicriteria approach to a city, Nat. Hazards Earth Syst. Sci., 9, 1881-1895, doi:10.5194/nhess-9-1881-2009, 2009.

Landis, W. G. (Ed.): Regional Scale Ecological Risk Assessment, Using the Relative Risk Model, CRC Press, Boca Raton, FL, USA, 2005.

Landis, W. G. and Wiegers, J. A. : Design Considerations and a Suggested Approach for Regional and Comparative Ecological Risk Assessment, Human Ecol. Risk Assess., 3, 287-297, 1997.

Mazzorana, B., Hübl, J., and Fuchs, S.: Improving risk assessment by defining consistent and reliable system scenarios, Nat. Hazards Earth Syst. Sci., 9, 145-159, doi:10.5194/nhess-9-1452009, 2009.

Mazzorana, B., Levaggi, L., Keiler, M., and Fuchs, S.: Towards dynamics in flood risk assessment, Nat. Hazards Earth Syst. Sci., 12, 3571-3587, doi:10.5194/nhess-12-3571-2012, 2012.

Mebarki, A., Valencia, N., Salagnac, J. L., and Barroca, B.: Flood hazards and masonry constructions: a probabilistic framework for damage, risk and resilience at urban scale, Nat. Hazards Earth Syst. Sci., 12, 1799-1809, doi:10.5194/nhess-12-17992012, 2012.

Menne, B. and Murray, V.: Floods in the WHO European Region: Health Effects and Their Prevention, World Health Organization, Regional Office for Europe (WHO), edited by: Menne, B. and Murray, V., Copenhagen, Denmark, 2013.

Meyer, V., Scheuer, S., and Haase, D.: A multicriteria approach for flood risk mapping exemplified at the Mulde river, Germany, Nat. Hazards, 48, 17-39, 2009

Mitchell, J. K.: European river floods in a changing world, Risk Anal., 23, 567-574, 2003.

Montanari, A., Young, G., Savenije, H. H. G., Hughes, D., Wagener, T., Ren, L. L., Koutsoyiannis, D., Cudennec, C., Toth, E., Grimaldi, S., Bloschl, G., Sivapalan, M., Beven, K., Gupta, H., Hipsey, M., Schaefli, B., Arheimer, B., Boegh, E., Schymanski, S. J., Di Baldassarre, G., Yu, B., Hubert, P., Huang, Y., Schumann, A., Post, D. A., Srinivasan, V., Harman, C., Thompson, S., Rogger, M., Viglione, A., McMillan, H., Characklis, G., Pang, Z., and Belyaev, V.: "Panta Rhei-Everything Flows": Change in hydrology and society-The IAHS Scientific Decade 2013-2022, Hydrol. Sci. J., 58, 1256- 1275, 2013.

Nedvedová, K. and Pergl, R.: Cultural heritage and flood, CESB 2013 PRAGUE - Central Europe Towards Sustainable Building 2013: Sustainable Building and Refurbishment for Next Generations, Prague, Czech Republic, 2013.

Papathoma-Kohle M., Kappes M., Keiler M., and Glade T.: Physical vulnerability assessment for alpine hazards: State of the art and future needs, Nat. Hazards, 58, 645-680, 2011.

Pappenberger, F., Stephens, E., Thielen, J., Salamon, P., Demeritt, D., van Andel, S. J., Wetterhall, F., and Alfieri, L.: Visualising probabilistic flood forecast information: expert preferences and perceptions of best practice in uncertainty communication, Hydrol. Process., 27, 132-146, 2013.
Pasini, S., Torresan, S., Rizzi, J., Zabeo, A., Critto, A., and Marcomini, A.: Climate change impact assessment in Veneto and Friuli Plain groundwater. Part II: A spatially resolved regional risk assessment, Sci. Total Environ., 440, 219-235, 2012.

Penning-Rowsell, E., Floyd, P., and Ramsbottom D.and Surendran, S.: Estimating injury and loss of life in floods: a deterministic framework, Nat. Hazards, 36, 43-64, 2005.

Preston, B. L., Smith, T. F., Brooke, C., Gorddard, R., Measham, T. G., Withycombe, G., Mcinnes, K., Abbs, D., Beveridge, B., and Morrison, C.: Mapping Climate Change Vulnerability in the Sydney Coastal Councils Group, prepared for the Sydney Coastal Councils Group and the Commonwealth Department of Climate Change by the CSIRO Climate Adaptation Flagship, Canberra, 2008.

Ronco, P., Bullo, M., Torresan, S., Critto, A., Olschewski, R., Zappa, M., and Marcomini, A.: The KULTURisk Regional Risk Assessment methodology for water-related natural hazards - Part 2: Application to the Zurich case study, Hydrol. Earth Syst. Sci. Discuss., 11, 7875-7933, doi:10.5194/hessd-11-7875-2014, 2014.

Rotach, M. W., Arpagaus, M., Dorninger, M., Hegg, C., Montani, A., and Ranzi, R.: Uncertainty propagation for flood forecasting in the Alps: different views and impacts from MAP D-PHASE, Nat. Hazards Earth Syst. Sci., 12, 2439-2448, doi:10.5194/nhess-12-2439-2012, 2012.

Scholz, R. and Tietje, O.: Formative scenario analysis, in: Embedded case study methods, edited by: Scholz, R. and Tienje, O., Sage, Thousand Oaks, 79-116, 2002.

Schwarz, J. and Maiwald, H.: Damage and loss prediction model based on the vulnerability of building types, 4th International Symposium on Flood Defence: Managing Flood Risk, Reliability and Vulnerability. Toronto, Ontario, Canada, 6-8 May, 74-1 to $74-9,2008$.

Torresan, S., Critto, A., Rizzi, J., and Marcomini, A.: Assessment of coastal vulnerability to climate change hazards at the regional scale: the case study of the North Adriatic Sea, Nat. Hazards Earth Syst. Sci., 12, 2347-2368, doi:10.5194/nhess-12-23472012, 2012.

Totschnig R. and Fuchs, S.: Mountain torrents: quantifying vulnerability and assessing uncertainties, Eng. Geol., 155, 31-44, 2013.

UNESCO: Convention concerning the protection of the world cultural and natural heritage, Adopted by the General Conference at its seventeenth session Paris, 16 November 1972.

Viglione, A., Di Baldassarre, G., Brandimarte, L., Kuil, L., Carr, G., Salinas, J. L., Scolobig, A., and Bloschl, G.: Insights from socio-hydrology modelling on dealing with flood risk - Roles of collective memory, risk-taking attitude and trust, J. Hydrol., 518, 71-82, 2014.

Vincke, P.: Multi-criteria decision aid. John Wiley and Sons, UK, SBN: 978-0-471-93184-3, 174 pp., 1992.

WMO: World Meteorological Organization: Integrated Flood Management as an Adaptation Tool for Climate Change: Case Studies, APFM Technical Document No. 15, Flood Management Tools Series, Associated Programme on Flood Management, Geneva, 2011.

Yahaya, S., Ahmad, N., and Abdalla, R. F.: Multicriteria analysis for flood vulnerable areas in Hadejia-Jama' are River basin, Nigeria, Eur. J. Sci. Res., 42, 71-83, 2010. 
Yosie, T. F. and Herbst, T. D.: Using Stakeholder Processes in Environmental Decision making. An Evaluation of Lessons Learned, Key Issues, and Future Challenges, American Industrial Health Council, Ruder Finn, Washington, 1998.

Zabeo, A., Pizzol, L., Agostini, P., Critto, A., Giove, S., and Marcomini, A.: Regional risk assessment for contaminated sites Part 1: Vulnerability assessment by multicriteria decision analysis, Environ. Int., 37, 1295-1306, 2011.
Zald, A. E., Summer, S., and Wade, T.: A to Z GIS: An Illustrated Dictionary of Geographic Information Systems, Information Bulletin, 38, 118 pp., 2006. 